Article

\title{
Does Public-Loan Management Matter for Sustainable Finance and Operation Risk?
}

\author{
Won Woo Rhee and Hong-Youl Ha *[C]
}

Department of International Trade, Dongguk University-Seoul, Seoul 04620, Korea; ww-lee-36@hanmail.net

* Correspondence: hyha@dongguk.edu

\begin{abstract}
Previous research indicates that small-loan financing is a highly complex process, particularly when public sources provide financial support. This study applies propensity score matching to improve the effectiveness of closer inspection systems. Specifically, it compares before and after implementing propensity score matching (PSM) in terms of closer inspection and operational risk. It also examines similarities and differences among individuals' demographics regarding the default rate of small business loans. Data pertaining to 589,648 Sunshine Loan debtors are utilized to address the research questions. Results indicate that the default rate with closer inspection is $5.5 \%$ lower than without closer inspection. Furthermore, the default rate with operational risk is dramatically lower $(15.4 \%)$ than that without operational risk. The PSM approach presented here thus illuminates opportunities and challenges in three strategic areas: (1) management of public funds, (2) effectiveness of both closer inspection and operational risk, and (3) risk management for individual borrower types.
\end{abstract}

Keywords: sustainable finance; public loan; credit risk; portfolio management

check for

updates

Citation: Rhee, W.W.; Ha, H.-Y. Does Public-Loan Management Matter for Sustainable Finance and Operation Risk? Sustainability 2022, 14, 1453. https://doi.org/10.3390/su14031453

Academic Editor: Helen Chiappini

Received: 16 December 2021

Accepted: 25 January 2022

Published: 27 January 2022

Publisher's Note: MDPI stays neutral with regard to jurisdictional claims in published maps and institutional affiliations.

Copyright: (c) 2022 by the authors. Licensee MDPI, Basel, Switzerland. This article is an open access article distributed under the terms and conditions of the Creative Commons Attribution (CC BY) license (https:// creativecommons.org/licenses/by/ $4.0 /)$.

\section{Introduction}

Sustainable finance plays a strategic role for small and medium enterprises (SMEs), allowing such organizations to accomplish long-term business growth [1-3]. However, previous research indicates that small-loan financing can be a highly complex proposition, particularly in situations where funding is provided by public sources $[4,5]$. Prior research in this area has focused primarily on relatively small—and often family-owned-businesses. However, further research focusing on minimizing potential losses from bad loans is required to enhance the efficiency of the loan process and reduce losses. Such an approach is directly linked to sustainable risk management used by banking institutions when identifying credit for small business borrowers.

One of the main roles of banking institutions in Korea is dealing with public guaranteed loans for SMEs. The loans SMEs require are related to credit identification and operating activity risk $[6,7]$. A recent article demonstrated that a better understanding of SMEs' debt regarding the financial stability is essential for increasing the discriminative power of the credit rating model [8]. Accordingly, the following research question arises: How does evaluating SMEs' credit rating contribute to the stability of public guaranteed loans in Korea?

Current research seeks to answer this question by utilizing propensity score matching (PSM) to assess the effectiveness of closer inspection systems in the context of small loans. Despite the considerable attention policymakers give to supporting small businesses, research on this topic is still in its infancy. In addition, it also utilizes loan applicant demographics in the context of small loans. Thus, this study aims to contribute to both the research and practice not just by applying the PSM approach for the first time in this context but also by providing a more thorough understanding of public funding operations to reduce their default rates and, thus, financial risk.

Another contribution is that using PSM to reduce the default rate of debt is beneficial to small business loan prevention, improving institutions' financial soundness. Researchers 
demonstrate that firms engage in illegality and suffer the penalties of so doing [9,10]. This study is notable because it considers the default risk of small business loans between borrowers and banks.

Furthermore, the extant literature provides meaningful insights when applying PSM to study various contexts. However, unlike prior research, the current study compares several variables related to defaults after comparing results of before and after the implementation of PSM methods. Thus, this study contributes to the literature by comparing and analyzing the closer inspection of small-loan finance. Since, to date, minimal research has utilized the PSM approach in the financial services market, this study aims to provide valuable guidance for enhancing small loan financing and reducing risk in small business lending.

As the context of this study is South Korea, an overview of the South Korean small loan financing environment is first presented, after which the research model is developed. Using PSM, it is argued that closer inspection and operational risk each play an important role in preventing small business loans and ethical laxity. Subsequent sections summarize the methodology, analysis procedures, and results. Finally, the implications both for research and practice are identified.

\section{Research Background}

\subsection{The Sunshine Loan in South Korea}

The Sunshine Loan (i.e., a type of small public guaranteed loan) introduced in 2010, is a subprime unsecured personal loan by non-bank depository institutions in South Korea. It typically operates as follows: When financial institutions issue Sunshine Loans to individuals with low income or bad credit, the Korean Credit Guarantee Foundation partially guarantees the loans. From January 2010 through December 2014, this loan has provided valuable assistance to many small businesses in financial difficulties [11]. People who qualify for a Sunshine Loan are typically workers, micro- or small-business owners, and those subject to warranty restrictions. Sunshine Loans can be divided into three categories: refinance loans, livelihood loans for workers, and operating loans for small-business owners. In 2014, the rate of closer inspections (closer inspections/guarantee supply) was $11.6 \%$ $(20,638 / 178,056)$, while the rate of suspect information (suspect information/guarantee supply) was $1.4 \%(2517 / 178,056)$.

Although there are several advantages of the Sunshine Loan program, it is also accompanied by a high credit default rate, which adversely affects financial institutions and is directly related to many individuals using these loans as a hedging instrument for debt repayment or declaring intentional bankruptcy [12]. Researchers point out that market forces are still not creating an adequate supply of lower-interest-rate subprime unsecured personal loans and that non-bank depository institutions have failed to demonstrate a capacity for preliminary screening or follow-up management in issuing Sunshine Loans [13]. This situation has arisen because, if the guaranteed rate is too low, financial institutions will avoid issuing Sunshine Loans, which could reduce the program's effectiveness [13]. In addition, a recent study highlights a better understanding of the risk of loans guaranteed by public credit guarantee schemes [14].

In considering this background, the current research proposes that a PSM approach could potentially be utilized to further enhance the effectiveness of closer inspections in the context of small public guaranteed loans. This approach is acceptable because, at least in the Korean public sectors, PSM is universally used to compare support and non-support groups before and after the issuance of Sunshine Loans [15]. Although this study is conducted in South Korea, implications can be applied elsewhere, as the Sunshine Loan program closely resembles the structure of other microcredit programs such as ADIE in France, DMI in Germany, and ACCION in the United States.

\subsection{Current Scrutiny Measures and Screening for Smal Business Loans}

The scrutiny process involves additional investigation after a guaranteed applicant fits the screening types set by a guarantee institution. Similarly, illegal loan prevention 
screening (ILPS) is a guarantee process involving additional investigation if a credit rating firm suspects risky small business loan information. This process helps the financial institution maintain its financial soundness and sustainability, and in turn, it assists SMEs in increasing their competitiveness in the market [16]. As shown in Table 1, the number of guarantees supplied in 2014 was 178,056, and the number of closer inspections was 20,638 (11.6\%). Meanwhile, the number of incidences of suspect information was 2517 (1.4\%) in 2014 (see Table 2). Table 3 shows specified types of loan applicants. Consequently, these findings report misuse of funds meant for small-loan public finance businesses by financial institutions that resulted in underperformance.

Table 1. Closer inspection status of sunshine loans: the case of workers.

\begin{tabular}{|c|c|c|c|c|c|}
\hline & $2010 *$ & 2011 & 2012 & 2013 & 2014 \\
\hline Closer supply & 7328 & 33,508 & 52,324 & 187,974 & 178,056 \\
\hline Closer inspection & 1172 & 9600 & 20,501 & 16,851 & 20,638 \\
\hline Screening ratio & 16.0 & 28.6 & 39.2 & 9.0 & 11.6 \\
\hline
\end{tabular}

Table 2. AFDS status of sunshine loans.

\begin{tabular}{cccccc}
\hline & $\mathbf{2 0 1 0}$ & $\mathbf{2 0 1 1}$ & $\mathbf{2 0 1 2}$ & $\mathbf{2 0 1 3}$ & $\mathbf{2 0 1 4}$ \\
\hline Guaranteed supply & 170,323 & 33,508 & 52,324 & 187,974 & 178,056 \\
Suspect information & 2706 & 918 & 1611 & 3872 & 2517 \\
Suspect information ratio & 1.6 & 2.7 & 3.1 & 2.1 & 1.4 \\
\hline
\end{tabular}

Table 3. Default ratio of sunshine loans with closer inspection system.

\begin{tabular}{cccc}
\hline & Default & Total & Default Ratio \\
\hline Overlapping applicants and under 1 year & 8282 & 33,048 & 25.1 \\
Temporary workers and under 4 months & 3191 & 13,061 & 24.4 \\
Rejecters (or re-applicants) & 80 & 612 & 13.1 \\
Cash recipients & 132 & 797 & 16.6 \\
Senior citizen and temporary workers and under 1 year & 38 & 475 & 8.0 \\
Suspect application information & 420 & 7351 & 5.7 \\
\hline
\end{tabular}

\subsection{PSM Approach and Models}

PSM has become a popular approach for estimating causal treatment effects across a broad range of disciplines [17]. It is an approach that allows researchers to match individuals in a treatment group to others who did not participate but have comparable characteristics [18]. Importantly, Rosenbaum and Rubin [19] demonstrate that when many characteristics are used in the matching process, PSM can be used to select comparison groups whose members are similar, on average, in terms of these characteristics.

In particular, increased attention should be paid to the relationship between marketbased private funding and non-market-based public funding that can be considered interventions in a statistical sense. For example, one may argue that public loan management does not happen on a market basis and, therefore, loan management can be considered treatment. On the other hand, private loans also occur, but since that happens on a market basis, they cannot be considered as interventions in the market (=treatment). Since this study focuses specifically on small business loan borrowers, it is evident that this approach is not only relevant for public loan management. In addition, recent studies in public loan areas are gradually evolving to a market basis [20].

As shown in Table 4, there are two types of PSM models: 1:1 and 1:n. The former is the one-to-one matching method between the experimental and control groups, closely related to propensity scores. Similarly, the latter is the one-to-many matching method between a control group and experimental groups. This study only allows 1:1 matching 
using logistic regression and fuzzy matching with a propensity score estimating algorithm and matching algorithm.

Table 4. PS matching method.

\begin{tabular}{|c|c|c|c|}
\hline & PS Matching & PS Matching (3.0) & PS Matching (3.0.3) \\
\hline & IBM & \multicolumn{2}{|c|}{ Felix Thoemmes } \\
\hline Estimate algorithm & Logistic regression & Logistic regression & $\begin{array}{l}\text { Logistic regression } \\
\text { GAM logit }\end{array}$ \\
\hline Matching algorithm & FUZZY & Nearest neighbor & $\begin{array}{c}\text { Nearest neighbor } \\
\text { Full } \\
\text { Optimal }\end{array}$ \\
\hline Characteristics & $\begin{array}{c}\text { Easy identification } \\
\text { 1:1 matching } \\
\text { Matching limitation } \\
\text { through a tolerance }\end{array}$ & $\begin{array}{l}\text { Various propensity } \\
\text { scores and graphs } \\
\text { 1:1 and 1:n matching } \\
\text { Limitation of matching } \\
\text { subjects using calipers }\end{array}$ & $\begin{array}{c}\text { Various propensity } \\
\text { scores and graphs } \\
\text { 1:1 and 1:n matching } \\
\text { Limitation of matching } \\
\text { subjects using calipers } \\
\text { Smoothing of covariance using } \\
\text { GAM logit }\end{array}$ \\
\hline
\end{tabular}

The model's propensity score is expressed as a conditional probability designed by Rosenbaum and Rubin [19]. In Formula (1), $e(X)$ denotes propensity score, $p$ is the probability, and $Z$ denotes treatment assignment with 1 (treatment group) and 0 (control group). I means conditional on, and $X$ means a vector of covariates.

Given that all explanatory variables ( $X$, vector of covariates) are conditional, we use the occurrence probability value of the experimental group (1). Meanwhile, with PSM, if there is an imbalanced distribution before matching, it is necessary to make a similar distribution between the experimental and control groups after matching. Furthermore, the greatest challenge with PSM is not to pair one or two covariates but simultaneously pair several variables with similar characteristics.

$$
e(X)=p(Z=1 \mid X)
$$

Based on Formula (1), subjects are classified to balance off $X$ distribution based on the propensity score of the population. More specifically, if a conditional probability is given, both the covariate variable, $X$, and the state variable for processing, $Z$, are independent when a propensity score, $e(x)$, is given. Thus, if $X$ and $Z$ are independent, then the propensity score is $e(x) \neq 0$, full randomization is impossible, and " 1 " indicates the need for estimating the propensity score. Therefore, Formula (2) is expressed as follows:

$$
P(X, Z \mid e(x))=p[X \mid e(x) * p(Z \mid e(x)]
$$

\subsection{Research in PSM}

There have been numerous studies on propensity score matching (PSM), particularly in the South Korean context. For example, Kim and Baek [21] demonstrate that using PSM is very useful for identifying the characteristics of respondents' personalities. Lee and Moon [22] highlight the effectiveness of PSM methods in evaluating a basic pension scheme for seniors. The method also effectively analyzes the official Korean stock market, (KOSDAQ) [23]. Similarly, Dehejia and Wahda [24] have used PSM to assess the labor market. Traugot [25] found a variety of possibilities when comparing and analyzing data traits, particularly in the context of the general election. Moreover, Rubin and Thomas [26] recommend that sample survey data are applied when estimating a PSM. Finally, Fier [27] demonstrated that R\&D expenditures are also well-identified and estimated by PSM.

However, we argue that research on the effect of small public loans or microfinance using PSM is still in its infancy. For example, researchers report a lack of evidence of trans- 
formative effects on SME borrowers [28]. Furthermore, previous studies on labor markets and associated biases could differ in the context of small loans or microfinance [29]. While the literature on small loan financing that estimates the impact of small-loan finance on actual borrowers is still shrouded in controversy [30,31], this study serves as an important addition to the limited literature on small-loan evaluation. In particular, interventions to promote access to finance for SEMs constitute a critical component of governments' effective public financing strategies [5,32]. By comparing the estimates of before and after the implementation of PSM, we can reduce operational risk on actual public-loan estimates and shed light on the potential magnitude of small-loan spirit bias.

\section{Methodology}

\section{Data Collection and Research Settings}

This study utilizes Sunshine Loan guarantee data from August 2010 to December 2015, which includes 524,974 cases total, with 60,382 closer inspection cases and 4292 cases of preventing small business loan screening. As previously outlined, this research considers eight variables for PSM (i.e., guarantee amount, guaranteed rate, service period length [month], annual income, credit level, age, financial institution, and employment form). As shown in Table 5, these variables were chosen because when estimating scrutiny and preventing small business loan screening, the National Credit Guarantee Foundation Federation (the main credit guarantee organization founded by the South Korean government) considers them the most critical variables in this context.

Table 5. Classification of variables.

\begin{tabular}{cc}
\hline Variable & Classification \\
\hline Guarantee amount & Won (Korea) $(1203=$ US $\$ 1)$ \\
Guarantee ratio & $85 \%, 90 \%, 95 \%$ \\
Continuous service period & Month \\
Income & Won \\
Credit rating & Low (7-10), Middle (5-6), High (1-4) \\
Age & Year \\
Bank & 6 banks \\
Employee status & Full-time worker, temporary worker, \\
Default & undeclared income, daily worker \\
Default ratio & Won \\
Closer inspection & Case \\
Operational risk & Case \\
\hline
\end{tabular}

Finally, our approach used logistic regression to estimate two types of matching models for assessing scrutiny and small business loan screening. It is common to estimate the propensity score by logit using a bivariate variable, indicating whether SMEs are defaulted. More specifically, we estimated the score using treatment assignment as the dependent variable and all selected variables forced as covariates.

\section{Results}

\subsection{Basic Statistics}

The basic statistics obtained from matching both scrutiny and small business loan screening showed significant differences among the eight variables. In particular, guaranteed rate, annual income, and age showed meaningful differences (see Table 6). 
Table 6. Basic Statistics.

\begin{tabular}{|c|c|c|c|}
\hline & Before Matching & $\begin{array}{c}\text { After Closer } \\
\text { Inspection Matching }\end{array}$ & $\begin{array}{c}\text { After Operational } \\
\text { Risk Matching }\end{array}$ \\
\hline Guaranteed amount & $7,729,677$ & $7,062,056$ & $7,297,964$ \\
\hline \multirow{3}{*}{ Guaranteed ratio } & $26.8(85 \%)$ & $63.3(85 \%)$ & $50.0(85 \%)$ \\
\hline & $30.6(90 \%)$ & $13.7(90 \%)$ & $23.0(90 \%)$ \\
\hline & $42.6(95 \%)$ & $23.0(95 \%)$ & $27.0(95 \%)$ \\
\hline $\begin{array}{l}\text { Continuous service } \\
\text { period }\end{array}$ & 29.2 & 27.4 & 31.6 \\
\hline Income & $20,419,633$ & $19,044,263$ & $19,514,218$ \\
\hline \multirow[t]{3}{*}{ Credit rating } & 31.0 (low) & 39.4 (low) & 38.6 (low) \\
\hline & 56.6 (middle) & 50.0 (middle) & 51.1 (middle) \\
\hline & 12.4 (high) & 10.5 (high) & 10.3 (high) \\
\hline Age & 36.7 & 37.2 & 39.1 \\
\hline \multirow[t]{6}{*}{ Bank } & NFCF $(0.3 \%)$ & NFCF $(0.4 \%)$ & NFCF $(0.1 \%)$ \\
\hline & SB $(56.9 \%)$ & SB $(31.0 \%)$ & SB $(37.8 \%)$ \\
\hline & KFCCC $(13.0 \%)$ & KFCCC $(19.6 \%)$ & KFCCC $(13.0 \%)$ \\
\hline & NFFC $(0.8 \%)$ & NFFC $(1.2 \%)$ & NFFC $(1.4 \%)$ \\
\hline & NCUFK $(14.0 \%)$ & NCUFK $(17.9 \%)$ & NCUFK $(16.0 \%)$ \\
\hline & NH $(15.0 \%)$ & $\mathrm{NH}(29.9 \%)$ & NH $(31.7 \%)$ \\
\hline \multirow[t]{4}{*}{ Employee status } & Full-time $(80.9 \%)$ & Full-time $(73.9 \%)$ & Full-time $(76.7 \%)$ \\
\hline & Temporary $(12.7 \%)$ & Temporary (18.9\%) & Temporary $(15.3 \%)$ \\
\hline & Undeclared (5.1\%) & Undeclared $(5.0 \%)$ & Undeclared $(6.0 \%)$ \\
\hline & Daily $(1.3 \%)$ & Daily $(2.3 \%)$ & Daily (2.1) \\
\hline
\end{tabular}

Note: NFCF = National Forestry Cooperative Federation; SB = savings bank; KFCC $=$ Korean Federation of Community Credit Cooperatives; NFFC $=$ National Federation of Fisheries Cooperatives; NCUFK = National Credit Union Federation of Korea; $\mathrm{NH}=$ NongHyup.

\subsection{Results of PSM}

As shown in Table 7 , the $\chi^{2}$ value of closer inspection was 811.498 , indicating statistical significance at $p<0.001$. The model of operational risk was also statistically significant $\left(\chi^{2}=1537.226\right)$ at $p<0.001$. While all matching variables of the closer inspection model were significant, both income and credit rating were not significant. Meanwhile, employee status for the closer inspection showed a 0.267 increase compared with other variables, whereas the bank variable for the operational risk showed a 0.032 increase.

The results of matching tolerance and incremental rejection are presented in Table 8 . When the value of the matching tolerance equals one, the results of fuzzy matching for closer inspection $(n=60,382)$ and operational risk $(n=4292)$ each had zero percent $(0.000 \%)$ of incremental rejection, indicating that the matching model was statistically significant.

Since the matching model is statistically significant, it was considered appropriate for comparing possible similarities and differences before and after PSM (see Table 9). Interestingly, the results show that all default rates increase after matching (in comparison to before matching). More specifically, these results can be used to estimate default rates in the future if closer inspection or operational risk are not conducted. Table 9 highlights how much default rates have to be decreased in each segmented level of variable types. In cases of closer inspection, default rates increase for variables such as under four months $(-12.4 \%)$, undeclared income $(-9.8 \%), 10-30$ million $(-11.9 \%)$, the middle level of credit rating $(-8.1 \%)$, and savings banks $(-13.4 \%)$.

In cases of operational risk, there are similarities and differences compared to the closer inspection matching. The similarity is an increased default rate in all the same categories, while the difference is in levels of default rates. Therefore, these levels range from $-12.0 \%$ (the median credit rating) to $-25.6 \%$ (undeclared income). Consequently, these results change in each characteristic, which significantly affects default incidence. 
Table 7. Results of logistic regression.

\begin{tabular}{|c|c|c|c|c|c|c|}
\hline $\begin{array}{c}\text { Closer } \\
\text { Inspection }\end{array}$ & Matching Variable & B & Wald & $\operatorname{Exp}(b)$ & $x^{2}$ & $-2 L L$ \\
\hline & Constant & -4.009 & $1209.354^{* *}$ & 0.018 & $811.498^{* *}$ & $366,595.886$ \\
\hline & Guaranteed amount & $-3.217 \times 10^{-8}$ & $242.528^{* *}$ & 1.000 & & \\
\hline & Guaranteed ratio & 0.025 & $447.561 * *$ & 1.026 & & \\
\hline & Continuous service period & -0.010 & $2946.149 * *$ & 0.990 & & \\
\hline & Income & $-3.536 \times 10^{-9}$ & $29.946^{* *}$ & 1.000 & & \\
\hline & Credit rating & 0.054 & $50.773 * *$ & 1.005 & & \\
\hline & Age & -0.008 & $267.061 * *$ & 0.992 & & \\
\hline & Bank & 0.027 & $74.848^{* *}$ & 1.027 & & \\
\hline & Employee status & 0.237 & $1443.934^{* *}$ & 1.267 & & \\
\hline \multirow[t]{9}{*}{$\begin{array}{c}\text { Operational } \\
\text { risk }\end{array}$} & Constant & 18.414 & $1611.684^{* *}$ & $9.93 \times 10^{7}$ & $1537.226^{* *}$ & $48,271.407$ \\
\hline & Guaranteed amount & $1.877 \times 10^{-8}$ & $7.239 * *$ & 1.000 & & \\
\hline & Guaranteed ratio & -0.136 & 824.986 ** & 0.873 & & \\
\hline & Continuous service period & 0.004 & $69.962 * *$ & 1.004 & & \\
\hline & Income & $-1.024 \times 10^{-9}$ & 0.220 & 1.000 & & \\
\hline & Credit rating & -0.039 & 2.191 & 0.961 & & \\
\hline & Age & -0.032 & 434.384 ** & 0.969 & & \\
\hline & Bank & 0.032 & $7.646^{* *}$ & 1.032 & & \\
\hline & Employee status & -0.025 & $29.282 * *$ & 0.88 & & \\
\hline
\end{tabular}

Note: ${ }^{* *}, p<0.01 ; \mathrm{B}=$ unstandardized coefficient; $\operatorname{Exp}(\mathrm{b})=$ odds ratio; $-2 \mathrm{LL}=-2$ Log likelihood.

Table 8. Matching tolerance and incremental rejection.

\begin{tabular}{cccc}
\hline & Value & Fuzzy Matching & $\begin{array}{c}\text { Incremental } \\
\text { Rejection (\%) }\end{array}$ \\
\hline Closer inspection & 1.000 & 60,382 & 0.000 \\
Operational risk & 1.000 & 4292 & 0.000 \\
\hline
\end{tabular}

As shown in Table 10, there are very strong effects associated with PSM. For example, the comparative results show that closer inspection after matching decreases the default rate (5.5\%) compared to non-closer inspection. Similarly, the default rate $(15.4 \%)$ dramatically decreases operational risk after matching. In line with these observations, guarantee defaults have powerful controlling effects. More specifically, the overall outcomes from before and after PSM reflect a decrease in default rates (i.e., closer inspection $=8.3 \%$ vs. operational risk $=13.3 \%$ ).

Table 9. Comparison before and after matching analysis.

\begin{tabular}{|c|c|c|c|c|c|c|c|c|c|}
\hline & & \multicolumn{2}{|c|}{$\begin{array}{l}\text { Before Closer } \\
\text { Inspection } \\
\text { Matching }\end{array}$} & \multicolumn{2}{|c|}{$\begin{array}{c}\text { After Closer } \\
\text { Inspection Matching }\end{array}$} & \multicolumn{2}{|c|}{$\begin{array}{c}\text { Before Operational } \\
\text { Risk Matching }\end{array}$} & \multicolumn{2}{|c|}{$\begin{array}{l}\text { After Operational } \\
\text { Risk Matching }\end{array}$} \\
\hline & & $\mathbf{Y}$ & $\mathbf{N}(\mathrm{A})$ & $\mathrm{N}(\mathrm{B})$ & $\Delta(A-B)$ & $\mathbf{Y}$ & $\mathrm{N}(\mathrm{C})$ & $\mathrm{N}(\mathrm{D})$ & $\Delta(C-D)$ \\
\hline \multirow{4}{*}{$\begin{array}{l}\text { Continuous } \\
\text { service } \\
\text { period }\end{array}$} & Under $4 \mathrm{M}$ * & 20.1 & 16.9 & 29.3 & -12.4 & 17.9 & 18.0 & 36.7 & -18.7 \\
\hline & $4 \mathrm{M}-1 \mathrm{Y}^{* *}$ & 17.7 & 17.2 & 26.6 & -9.4 & 16.6 & 17.3 & 31.0 & -13.7 \\
\hline & $1 \mathrm{Y}-2 \mathrm{Y}$ & 21.2 & 17.2 & 24.7 & -7.5 & 13.9 & 17.6 & 31.9 & -14.3 \\
\hline & Over 2 Y & 22.2 & 17.2 & 24.4 & -7.2 & 14.3 & 17.6 & 29.4 & -11.8 \\
\hline \multirow{4}{*}{$\begin{array}{l}\text { Employee } \\
\text { Status }\end{array}$} & Full-time & 21.1 & 17.2 & 25.9 & -8.7 & 15.6 & 17.6 & 30.9 & -13.3 \\
\hline & Temporary & 16.2 & 16.5 & 23.4 & -6.9 & 13.2 & 16.5 & 28.4 & -11.9 \\
\hline & Undeclared & 19.4 & 18.3 & 28.1 & -9.8 & 16.4 & 18.5 & 44.1 & -25.6 \\
\hline & Daily & 16.2 & 17.7 & 25.7 & -8.0 & 12.5 & 17.6 & 34.1 & -16.5 \\
\hline \multirow[t]{3}{*}{ Income } & Under $20 \mathrm{M}^{* * *}$ & 19.6 & 16.8 & 24.6 & -7.8 & 12.0 & 17.2 & 30.4 & -13.2 \\
\hline & $10 \mathrm{M}-30 \mathrm{M}$ & 20.0 & 16.8 & 28.7 & -11.9 & 18.3 & 17.2 & 33.5 & -16.3 \\
\hline & Over $30 \mathrm{M}$ & 23.1 & 20.1 & 27.9 & -7.8 & 21.1 & 20.1 & 33.6 & -13.5 \\
\hline
\end{tabular}


Table 9. Cont.

\begin{tabular}{|c|c|c|c|c|c|c|c|c|c|}
\hline & & \multicolumn{2}{|c|}{$\begin{array}{l}\text { Before Closer } \\
\text { Inspection } \\
\text { Matching }\end{array}$} & \multicolumn{2}{|c|}{$\begin{array}{c}\text { After Closer } \\
\text { Inspection Matching }\end{array}$} & \multicolumn{2}{|c|}{$\begin{array}{c}\text { Before Operational } \\
\text { Risk Matching }\end{array}$} & \multicolumn{2}{|c|}{$\begin{array}{l}\text { After Operational } \\
\text { Risk Matching }\end{array}$} \\
\hline & & $Y$ & $\mathbf{N}(\mathrm{A})$ & $\mathrm{N}(\mathrm{B})$ & $\Delta(\mathrm{A}-\mathrm{B})$ & $Y$ & $\mathrm{~N}(\mathrm{C})$ & $\mathrm{N}(\mathrm{D})$ & $\Delta(C-D)$ \\
\hline \multirow{3}{*}{$\begin{array}{l}\text { Credit } \\
\text { rating }\end{array}$} & High & 7.4 & 6.0 & 12.1 & -6.1 & 1.9 & 6.1 & 16.1 & -10.0 \\
\hline & Middle & 16.1 & 14.8 & 22.9 & -8.1 & 12.3 & 15.0 & 27.0 & -12.0 \\
\hline & Low & 29.8 & 26.3 & 31.3 & -5.0 & 27.1 & 26.7 & 37.0 & -10.3 \\
\hline \multirow[t]{6}{*}{ Bank } & NFCF & 22.4 & 24.0 & 33.0 & -9.0 & 14.3 & 23.8 & 0.0 & 23.8 \\
\hline & SB & 22.6 & 17.2 & 31.0 & -13.8 & 18.6 & 17.8 & 36.9 & -19.1 \\
\hline & KFCC & 17.3 & 17.5 & 26.8 & -9.3 & 10.4 & 17.5 & 31.8 & -14.3 \\
\hline & NFFC & 20.0 & 18.5 & 26.2 & -7.7 & 2.9 & 18.7 & 36.6 & -17.9 \\
\hline & NCUFK & 16.8 & 15.5 & 25.2 & -9.7 & 10.4 & 15.7 & 28.4 & -12.7 \\
\hline & $\mathrm{NH}$ & 16.4 & 18.2 & 23.9 & -5.7 & 7.3 & 18.0 & 30.0 & -12.0 \\
\hline
\end{tabular}

Notes: ${ }^{*}=$ Month; ${ }^{* *}=$ Year; ${ }^{* * *}=$ Million; A, B, C, and D in parentheses indicate default rates.

Table 10. Final analysis results.

\begin{tabular}{ccccc}
\hline & & $\begin{array}{c}\text { Default } \\
\text { Ratio }\end{array}$ & $\begin{array}{c}\Delta \text { Default } \\
\text { Ratio }\end{array}$ & \\
\hline Before & Closer inspection (A) & 20.0 & $\mathrm{C}=\mathrm{B}-\mathrm{A}$ & -2.8 \\
matching & Non-closer inspection (B) & 17.2 & & \multirow{2}{*}{ - } \\
& Operational risk (D) & 15.4 & $\mathrm{~F}=\mathrm{E}-\mathrm{D}$ & \multirow{2}{*}{5.5} \\
& Non-operational risk (E) & 17.5 & $\mathrm{I}=\mathrm{H}-\mathrm{G}$ & \multirow{2}{*}{15.4} \\
After & Closer inspection (G) & 20.0 & $\mathrm{~L}=\mathrm{K}-\mathrm{J}$ & \\
matching & Non-closer inspection (H) & 25.5 & 8.3 \\
& Operational risk (J) & 15.4 & 13.3 & \\
\hline Overall & Non-operational risk (K) & 30.8 & &
\end{tabular}

\section{Discussion}

Recent studies in public finance have focused on closer inspection and operational risk to reduce bad debt $[4,11,33]$. The current study offers a new perspective for evaluating loan applicants by applying PSM. This research is particularly timely as the effectiveness of closer inspection and operational risk are increasingly being questioned in South Korean public finance markets.

How can organizations engage in public finance decrease default rates and thus safeguard public funds? The approach presented here builds on the PSM framework [18] to provide insights for academics and practitioners to enhance the effectiveness of closer inspection and operational risk. Additionally, the PSM approach presented in this study illuminates opportunities and challenges in three strategic areas: (1) management of public funds, (2) effectiveness of closer inspection and operational risk, and (3) risk management for individual borrower types.

\subsection{Management of Public Funds}

A fundamental challenge in the management of public funds is deciding how to estimate small-loan borrowers and decrease default rates of credit guaranteed loans. The key decisions are related to establishing a credit limit and ensuring financial stability. In so doing, it is essential to estimate which strategic methods or approaches are optimal to identify and decrease financial default rates, particularly in the context of public funds [34].

Because managing healthy public funds depends on the ability of public financial organizations to operate sustainably and spread their resources across a broad spectrum of small and medium-sized entities (businesses and individuals), they must be careful 
in balancing their financial risks [35]. Based on the present research, it is proposed that managers utilize PSM procedures to reduce default rates. For instance, they can combine the guaranteed amount, guarantee ratio, continuous service period, income, credit rating, age, transactional bank, and employee status when evaluating small loan applicants. Public funding organizations can thus lower their risk and maintain effective management of public funds.

\subsection{Effectiveness of Closer Inspection and Operational Risk}

Closer inspections help lower default rates (5.5\%), demonstrating the effectiveness of this strategy both in terms of organizations' financial soundness and debtors' financial stability [3]. This result indicates that closer inspection plays an important role in reducing the frequency of distressed assets. Since assessing financial risk does not typically factor in as a main consideration of organizations engaged in public sector financing, this study proposes a PSM-based approach to enhance the effectiveness of closer inspections.

Checking operational risk is also a powerful control system to decrease default rates (15.4\%). As it has dynamic effectiveness, operation risk management plays a particularly crucial role in controlling debtors' immoral or unethical behaviors when applying for public credit funds. In keeping with the PSM approach, creating an information-sharing system between public financial organizations and credit rating agencies may be a good starting point to enhance the effectiveness of operational risk. For example, combining big data from each party takes advantage of decreasing default rates and increasing power to predict operational risk.

\subsection{Risk Management for Individual Types}

Risk management is necessary for the sustainability of public financial organizations in terms of reducing default rates. This study applies a risk perspective to test eight types of debtors who help to manage organization risks. In particular, managing different levels of default rates by employee status types is crucial for controlling risk levels, which affects organizations' financial soundness. Other individual types can be considered for developing strategies to protect against financial losses from a broad range of public fund customers. Managerial strategies for effective estimation include creating new hybrid forms of risk management.

Finally, the present analysis regarding the operation of closer inspection and operational risk for preventing bad loans builds on the body of research work on public financial markets. This study contributes to developing a methodological approach not previously used in the existing literature to understand financial data sets. In summary, it is possible to use a PSM approach when estimating consumers' credit worthiness. Moreover, since the PSM approach effectively reduces estimation errors (compared to multiple regression), it may be particularly beneficial to apply it in the sphere of finance [36].

\subsection{Research Limitations and Further Directions}

Although this research has practical implications, it possesses some notable limitations. First, the current study tested the effects of both closer inspection and operational risk using PSM. However, testing introduction timing is required to better understand the before or after-effects of closer inspection since the starting period of our data sets was August 2010. Second, choosing the best matching approach between one PSM approach and multiple PSM approaches is also useful. Although several PSM approaches have been developed for testing different research types, choosing an optimal approach is necessary for estimating default rates and managing risks, particularly in the financial area (see Appendix A).

\subsection{Conclusions}

We sought to understand a new perspective for evaluating loan applicants by applying PSM. This study builds upon the PSM framework, providing insight for academics and practitioners in terms of enhancing the effectiveness of closer inspection and operational 
risk. Closer inspections help lower default rates (5.5\%), demonstrating the effectiveness of this strategy both in terms of organizations' financial soundness and debtors' financial stability. Furthermore, the default rate with operational risk is dramatically lower $(15.4 \%)$ than that without operational risk. Therefore, the PSM approach presented in this study illuminates opportunities and challenges in three strategic areas: (1) management of public funds, (2) effectiveness of both closer inspection and operational risk, and (3) risk management for individual borrower types.

Author Contributions: Conceptualization, H.-Y.H. and W.W.R.; methodology, H.-Y.H.; software, W.W.R.; validation, H.-Y.H. and W.W.R.; formal analysis, H.-Y.H.; investigation, W.W.R.; resources, H.-Y.H.; data curation, W.W.R.; writing-original draft preparation, H.-Y.H.; writing-review and editing, H.-Y.H.; visualization, W.W.R.; supervision, H.-Y.H.; project administration, H.-Y.H. All authors have read and agreed to the published version of the manuscript.

Funding: This research received no external funding.

Institutional Review Board Statement: Not applicable.

Informed Consent Statement: Not applicable.

Data Availability Statement: Not applicable.

Conflicts of Interest: The authors declare no conflict of interest.

Appendix A. Frequency of Guaranteed Loan Borrowers

\begin{tabular}{ccc}
\hline & Frequency & Ratio \\
\hline \multicolumn{2}{c}{ Principal delay and overdue interest and principal and interest delay } \\
& 73,831 & 68.5 \\
\hline \multicolumn{3}{c}{ Bankruptcy application and application for supporting credit recovery } \\
& 1846 & 1.7 \\
\hline & 29,638 & 27.5 \\
\hline Application for individual recovery procedure and application for bankruptcy procedure \\
& The loss of benefit of time and death of a main debtor & 2.1 \\
\hline & 2281 & 0.2 \\
\hline Other & 152 & 100.0 \\
\hline Total & 107,748 &
\end{tabular}

\section{References}

1. Becchetti, L.; Trovato, G. The determinants of growth for small and medium sized firms: The role of the availability of external finance. Small Bus. Econ. 2002, 19, 291-306. [CrossRef]

2. Beck, T.; Demirguc-Kunt, A. Small and medium-size enterprises: Access to finance as a growth constraint. J. Bank. Financ. 2006, 30, 2931-2943. [CrossRef]

3. Tian, X.; Nie, P. Economic analysis of political connection affect corporate credit financing constraints based on fuzzy logic and SEM model. J. Intell. Fuzzy Syst. 2019, 37, 441-454. [CrossRef]

4. Kang, M.; Son, H.; Ha, H. Latent growth curve modeling for the relationship study between a new loan on security and a new loan on credit of credit union. J. Korea Serv. Manag. Soc. 2015, 16, 221-245. [CrossRef]

5. Mina, A.; Minin, A.D.; Martelli, I.; Testa, G.; Santoleri, P. Public funding of innovation: Exploring applications and allocations of the European SME instrument. Res. Policy 2021, 50, 104131. [CrossRef]

6. Liang, L.; Huang, B.; Liao, C.; Gao, Y. The impact of SEMs' lending and credit guarantee on bank efficiency in South Korea. Rev. Dev. Financ. 2017, 7, 134-141. [CrossRef]

7. Kang, J.W.; Heshmati, A. Effect of credit guarantee policy on survival and performance of SMEs in Republic of Korea. Small Bus. Econ. 2008, 31, 445-462. [CrossRef]

8. Lee, J. Verification test of high-stability SMEs using technology appraisal items. Inf. Syst. Rev. 2018, 20, 79-96. Available online: https: / /www.earticle.net/article/a345412 (accessed on 17 March 2021).

9. Greve, H.R.; Palmer, D.; Pozner, J. Organizations gone wild: The causes, processes, and consequences of organizational misconduct. J. Manag. Annu. 2010, 4, 53-107. [CrossRef] 
10. Jensen, M. Should we stay or should we go? Accountability, status anxiety, and client defections. Adm. Sci. Q. 2006, 51, 97-128. [CrossRef]

11. Pae, J.; Park, J.W.; Yun, S. Achievement of micro-credit policy in South Korea: Focusing on the Sunshine loan. Asia-Pac. J. Multimed. Serv. Converg. Art Humanit. Sociol. 2018, 8, 193-203. [CrossRef]

12. Ryu, D.W. Developing strategies of credit union: As financing source for small business startups. Asia-Pac. J. Bus. Ventur. Entrep. 2011, 6, 115-132. Available online: https:/ / koreascience.or.kr/article/JAKO201121641922124.page (accessed on 17 March 2021).

13. Oh, Y. Differentiating the guaranteed rate: A way to improve the Sunshine loan program. KDI Focus 2015, 40, 1-11. Available online: https: / / ssrn.com/abstract=2767398 (accessed on 17 March 2021).

14. Caselli, S.; Corbetta, G.; Cucinelli, D.; Rossolini, M. A survival analysis of public guaranteed loans: Does financial intermediary matter? J. Financ. Stab. 2021, 54, 100880. [CrossRef]

15. Kang, M.; Ha, H. Assessing the effect of Sunshine Loan's closer inspection and anti-fraud detection using propensity score matching. Serv. Mark. J. 2015, 8, 5-13. Available online: https:/ / www.earticle.net/article/a251105 (accessed on 17 March 2021).

16. Jose, S.; Chacko, J. Sustainable development of microfinance customers: An empirical investigation based on India. J. Enterp. Inf. Manag. 2017, 30, 49-64. [CrossRef]

17. Caliendo, M.; Kopeinig, I. Some practical guidance for the implementation of propensity score matching. J. Econ. Surv. 2008, 22, 31-72. [CrossRef]

18. Peikes, D.; Moreno, L.; Orzol, M. Propensity score matching: A note of caution for evaluators of social programs. Am. Stat. 2008, 62, 222-231. [CrossRef]

19. Rosenbaum, P.R.; Rubin, D.B. The central role of the propensity score in observational studies for causal effects. Biometrika 1983 70, 41-55. [CrossRef]

20. Mertens, D.; Thieman, M. Market-based but state-led: The role of public development banks in shaping market-based finance in the European Union. Compet. Change 2018, 22, 184-204. [CrossRef]

21. Kim, S.; Baek, J. On logistic regression analysis using propensity score matching. J. Appl. Reliab. 2016, 16, 323-330. Available online: https: / www.dbpia.co.kr/pdf/pdfView?nodeId=NODE07086188 (accessed on 17 March 2021).

22. Lee, J.; Moon, S. The effect of the basic pension to an income of seniors: Analysis by using PSM and DID. Korea Policy Stud. Rev. 2014, 23, 411-442. Available online: https:/ / kiss.kstudy.com/thesis/thesis-view.asp?key=3266655 (accessed on 17 March 2021).

23. Pyo, H.; Hong, S. Analyzing long-term achievement of listed companies in the KOSDAQ stock market by using PSM. Appl. Econ. 2013, 15, 39-71. Available online: https:/ / www.dbpia.co.kr/Journal/articleDetail?nodeId=NODE09038196 (accessed on 17 March 2021).

24. Dehejia, R.H.; Wahba, S. Causal effects in nonexperimental studies: Re-evaluation on the evaluation of training programs. J. Am. Stat. Assoc. 1999, 94, 1053-1062. [CrossRef]

25. Traugoot, M.W. Assessing poll performance the 2000 campaign. Public Opin. Q. 2001, 65, 389-419. Available online: https: / / www.jstor.org/stable/3078826 (accessed on 17 March 2021). [CrossRef]

26. Rubin, D.B.; Thomas, N. Combining propensity score matching with additional adjustment for prognostic covariates. J. Am. Stat. Assoc. 1992, 95, 573-585. [CrossRef]

27. Fier, A. The Impact of Government Funded R \& D Activities in German Industry. 2000. Available online: www.eea-esem.com/ eea-esem/2003/prog/getpdf/asp (accessed on 17 March 2021).

28. Banerjee, A.; Karlan, D.; Zinman, J. Six randomized evaluations of microcredit: Introduction and further steps. Am. Econ. J. Appl. Econ. 2015, 7, 1-21. [CrossRef]

29. Cintina, I.; Love, I. Re-evaluating microfinance: Evidence from propensity score matching. World Bank Econ. Rev. 2019, 33, 95-115. [CrossRef]

30. Pitt, M.; Khandker, S. The impact of group-based credit programs on poor households in Bangladesh: Does the gender of participants matter? J. Polit. Econ. 1998, 106, 958-998. [CrossRef]

31. Roodman, D.; Morduch, J. The impact on the poor in Bangladesh: Revisiting the evidence. J. Dev. Stud. 2014, 50, 583-604. [CrossRef]

32. Kersten, R.; Harms, J.; Liket, K.; Maas, K. Small firms, large impact? A systematic review of the SME finance literature. World Dev. 2017, 97, 330-348. [CrossRef]

33. Ngai, E.; Hu, W.T.; Wong, Y.Y.H.; Chen, Y.; Sun, X. The application of data mining techniques in financial fraud detection: A classification framework and an academic review of literature. Decis. Support Syst. 2011, 50, 559-569. [CrossRef]

34. Kim, E.; Kim, S. An analysis on the effects of macroeconomic variables on guarantee accidents. J. Hous. Urban Financ. 2019, 4, 51-82. [CrossRef]

35. Altman, E.I.; Saunders, A. Credit risk measurement: Developments over the last 20 years. J. Bank. Financ. 1998, 21, 1721-1742. [CrossRef]

36. Rubin, D.B.; Thomas, N. Characterizing the effect of matching using linear propensity score methods with normal distributions. Biometrika 1992, 79, 797-809. [CrossRef] 